\title{
The Evolution of Erasmus' Epistolary Style
}

\author{
CHARLES FANTAZZI
}

RÉSUMÉ: L'évolution du style épistolaire d'Érasine

Il existe de nombreuses preuves qu'Érasme a soigneusement planifié la publication de différents recueils de ses lettres. Pour d'autres lettres, il donna la permission qu'elles soient recopiées et distribuées. Il est intéressant, d'une part, d'étudier les critères qui ont déterminé la sélection de certaines lettres pour la publication et, d'autre part, d'examiner quelques-unes des lettres qui n'ont été incluses dans aucun recueil officiel. Ce faisant, on peut observer l'évolution du style versatile d'Érasme depuis ses expériences de jeunesse, quand il s'exerçait à l'art d'écrire, jusqu'aux premiers recueils officiels. Dans ses toutes premières lettres, les préceptes tirés de ses ouvrages pédagogiques, spécialement les Familiarium colloquiorum formulae et le De conscribendis epistolis, sont mis en pratique. La première apparition officielle d'un groupe de quatre lettres (1515) est un peu déguisée puisqu'elles forment la dernière partie d'une brève anthologie de poèmes et de lettres de louanges dédiécs au pape Léon X. Le deuxième recueil, Epistulae aliquot virorum illustrium ad Erasmum (1516), est surtout consacré à l'accueil favorable reçu par lc Novum Instrumentum. Les correspondants ont été choisis avec beaucoup de soin de même que l'ordre dans lequel les lettres apparaissent. Le troisième recueil, Epistulae sanequam elegantes (1517), est plus important et, comme l'indique le titre, les lettres sont très soignées.

Letters have long been studied mainly for their historical and biographical content, and only secondarily as works of literature, although it is commonly recognized that many collections of letters were carefully designed with a view to posterity. Often the writers of them were not able to see to the fulfilment of their wishes, Cicero being a prime example, who began only towards the end of his life to plan a collection of his letters as an illustration of his epistolary style, but nevcr brought his plan to fruition. ${ }^{1}$ The third-century orator, Symmachus, had the good fortune of having his

Renaissance and Reformation / Renaissance et Réforme, XXV, 3 (1989) 263 
son publish his letters, who carefully suppressed any that might be compromising. ${ }^{2}$ Petrarch spent much time correcting and revising his letters long after they were in the hands of the addressees, often with detrimental results, according to the great Italian philologist, Giorgio Pasquali, who said of them: 'Si cincischia troppo' / 'He fiddles with them too much. ${ }^{3}$ He often removed what he considered to be trivial particulars in the attempt, as it would seem, to impart to them a touch of eternity, at the expense of immediacy and spontaneity. To fill out the correspondence in places, he even went so far as to invent fictitious letters. Another humanist, Antonio Beccadelli, went still further in his work of revision, consciously falsifying many of his letters in order to make them more palatable for future readers. ${ }^{4}$

In the face of numerous redactions and exemplars, editors in the past have usually published the final version, as in the Edizione nazionale of Petrarch, ${ }^{5}$ but there are presently some editors of Renaissance epistolaries, especially in Italy, who would prefer to print the more authentic first version and give the modifications in the apparatus. ${ }^{6}$ In the case of Erasmus, Allen, as we know, printed the final version, as well as he could determine it from the varied tradition, viz., the letters that were published with Erasmus' full supervision or at least connivance, with usually only minor revisions; many more which he allowed to be collected and copied out but were not published in his lifetime; and a great number that were subsequently discovered throughout Europe. With respect to the published collections, there is abundant evidence that Erasmus carefully stage-managed their publication. ${ }^{7}$ It would be very tempting, therefore, to peek behind the scenes for just a brief moment, for the length of the play, to use a favorite image of Erasmus, precludes any sort of exhaustive treatment. A cursory look at the very earliest collections should reveal something concerning the criteria that determined the selection of certain letters for publication, but much may be learned as well from an examination of some of the early letters that did not gain admittance into any official collection. In the process we may observe the evolution of Erasmus' versatile style, that clusive, Protean instrument with which he both delighted his friends and confounded his enemies.

In order to appreciate the unique quality of the Erasmian epistolary style, it would be useful to rehearse very briefly certain moments in the history of the genre. From late antiquity the letter became fixed as an eminently rhetorical form. This can be seen most clearly in the Byzantine tradition, ${ }^{8}$ in which a highly stylized language was used, which bore little resemblance to the demotic form of spoken Greek. In the West the art of 
letter-writing also adhered to rigid formulas which can be traced back to Merovingian and Carolingian times. ${ }^{9}$ The most famous collection of these early formularies, dating from about the year 660 , is that of a certain Marcolf, a monk of Paris. These models greatly influenced the chancellery style of France and Italy. The full flowering of the genre, however, came about in the eleventh and twelfth centuries with the dominance of the professional practitioners of the craft of letter-writing, the so-called dictatores. 10

In the thirteenth century instruction in the ars dictaminis was accompanied by commentaries on Cicero's De inventione and the pseudo-Ciceronian Rhetorica ad Herennium, ${ }^{11}$ which reinforced the underlying pedagogical assumption that the rules of ancient oratory were applicable to the composition of letters. An important voice in the explicit joining of the two disciplines, as Professor Witt has recently pointed out, ${ }^{12}$ is that of Brunetto Latini, who in his two treatises on rhetoric admitted no difference between the letter and the speech save that the one was written and the other spoken. In both forms the precepts of Cicero were univocally relevant. The predominance of the Ad Herennium, in particular, continued into the following century with a great proliferation of commentaries on the work, including that of Giovanni di Bonandrea and the more famous one of his disciple, Bartolomeo di Benincasa, both of which became standard textbooks in the art of dictamen. ${ }^{13}$

At this advanced stage of evolution of the public letter, a very important event in the history of letter-writing and of humanism took place Petrarch's momentous discovery in the Chapter Library of Verona in May 1435 of a manuscript of Cicero's letters to Atticus, Quintus Cicero, and Brutus. In all probability he began in that same year to arrange his own letters into a collection, pruning and rewriting as he went. In the dedicatory letter addressed to Lodewijk Heiliger of Beringen, he reveals his criteria for the art of letter-writing, which are quite at variance with the teachings of dictamen. Indeed with the publication of the Epistolae de rebus familiaribus Petrarch put an end to the reign of the dictatores and their rigid prescriptions, which had inhibited the spontaneity of the personal letter for many centuries. ${ }^{14}$ 'Nulla hic equidem magna vis dicendi' / 'No great forcefulness of speech is to be found here.' 15 Petrarch states in the letter of dedication. He goes on to say that he would not use this type of clocution in his letters even if he possessed it, after the example of Cicero, who adopted an even, tempered style in his letters, reserving the full flood of his eloquence for the orations. In like manner, Petrarch promises to employ a plain, familiar type of language appropriate to the thoughts 
expressed: 'hoc mediocre, domesticum et familiare dicendi genus, amice, leges ... aptum accomodatumque sententiis. ${ }^{16}$ The chief concern of the writer is the identity of his correspondent. No longer are the form of address and general tone of the letter determined solely by social standing, but by the personal characteristics of the recipient: "A courageous man must be addressed in one way, a coward in another; an inexperienced youth in one way, an old man who has discharged his life's duties in another; in one way a person puffed up with good fortune, in another the person hemmed in by adversity; and finally a different approach is needed for the scholar famed for his talent and learning and the person who would not understand you if you were to use more elevated language. ${ }^{17}$ Both Erasmus and Vives in their manuals on letter-writing insist emphatically on this adaptation of style to the recipient, in terms very reminiscent of those of Petrarch. ${ }^{18}$

The principle of apte dicere, as elaborated by Quintilian, ${ }^{19}$ is at the heart both of Erasmus' theoretical concept of the style of the letter and his actual practice. According to the principle of ancient rhetoric known as ethopoiia, the speaker or writer should project a sympathetic image of himself, be familiar with his audience in order to make the desired impression, and provide fitting portrayals of the character of others as they are introduced into the narration. In these qualities Erasmus is probably without equal, but it must not be imagined for one moment that this apparently effortless facility was won without a long, hard apprenticeship in the study of language. As early as 1488 and extending through the 1490's Erasmus was diligently hammering out and perfecting his own style in an astonishing number of works: the first drafts of the Antibarbari, the epitome of Valla's Elegantiae linguae latinae, De ratione studii, Familiarium colloquiorum formulae, De copia, and, of course, De conscribendis epistolis. The minute attentiveness to the niceties of Latin style illustrated in these manuals owes its main inspiration to the Italian humanists. As Leonardo Bruni wrote as carly as 1422 in his De studiis et litteris, 'peritia literarum' must accompany 'scientia rerum.'20 Of these various pedagogical and rhetorical works of Erasmus, the rich compilation of Latin idiom and phraseology contained in the De copia is familiar to students of the Renaissance, but the preliminary draft of the Colloquia, i.e., the Familiarium colloquiorum formulae, written in his Paris days for his pupils Christian and Heinrich Northoff of Lübeck, is not that well known. ${ }^{21}$ It is interesting to scc Erasmus at work in these sketches prescribing phrases that may be used indifferently both in dialogue and letter-writing. At the same time he distinguishes modes of address more suitable in everyday speceh from 
those proper to letters, such as the method of returning greetings, the giving of thanks, and the wishing of good health, all of which will later be treated at greater length in De conscribendis epistolis. He also discusses various titles used in epistles commenting on their currency and propriety. For clerics and men of learning ornatissime is recommended, as is indeed Erasmus' common usage; celsitudo is more accepted than approved, although in practice Erasmus uses it quite often; praestantia, dominatio (both of these frowned upon in De conscribendis), ${ }^{22}$ and beatitudo may be used of certain dignitaries. ${ }^{23}$ Erasmus pronounces on the correctness or incorrectness of colloquial phrases, e.g., the response to the greeting 'quid agis?' / 'how are you?' with 'taliter qualiter' / 'so-so,' is ruled out as belonging to lingua culinaria / 'kitchen Latin.' 'Habeo te excusatum' is likewise disqualified from polite speech and therefore from the letter.

Sometimes these pedagogical musings are translated into the composition of actual letters. Letter 56, for example, addressed to Christian Northoff, was printed with the Colloquiorum formulae as an epistola protreptica, an exhortation to study. ${ }^{24}$ Letter 61 is an imaginative piece which Erasmus composes in the guise of Heinrich Northoff writing to his brother Christian in a sprightly, versatile style clearly beyond the literary ability of the alleged writer. Heinrich is represented as recounting a dream to his brother in which he imagines that Christian has abandoned the profane concerns of his mercantile career and has turned to the more lasting values of literary studies. Variations on this theme are found also in De conscribendis epistolis in a section on the presentation of the subject matter. ${ }^{25}$ Erasmus indulges in a bit of self-parody, in the person of Heinrich, who refers to his privileged status of hosting the celebrated Erasmus, which to him is like having Mount Helicon itself within the four walls of one's habitation. With good-humoured irony Erasmus also parodies Christian's attempt to use good Latin now that he has returned to Lübeck and is without his tutor's instruction. He puts these words into the mouth of Christian at the end of the dream: 'Ego vero tantam animo gratulationem concipio quantam exprimere omnino nequeam. Quod si par esset affectui dicendi facultas, gratularer tibi, o frater, oratione tam magnifica, tam copiosa, ut Cicero ipse numquam sit usus neque copiosiore neque magnificentiore' / 'The extent of the congratulations I conceive in my mind is greater than I am able to express; but if my power of utterance were equal to my sentiments of affection I should congratulate you in a speech so splendid, so elaborate that Cicero himself never produced anything more elaborate or more splendid.' Aside from the excessive fulsomeness of the language, in the second sentence of the Latin the prosaic 
chiasmus is made more ludicrous by the ungainly final rhythm, "neque copiosiore neque magnificentiore.' Thus in a jocular manner Erasmus demonstrates to his students what style not to use in a letter. At the Erasmian banquet of eloquence, as Heinrich commented earlier in the letter, where the urbane Campano and the exquisite Poliziano (politissimi ingenii, with a play on his name) are welcome guests, wit and urbanity are de rigeur, while pretentious solemnity is ruled out.

To these names Erasmus, alias Heinrich, might well have added that of Lorenzo Valla, with whose Elegantiae he was occupied at about the time this letter was written. Valla's treatise on style is a very important document in the evolution of the Latin language. Begun during his teaching career at Pavia and elaborated throughout his life-time, it lays the foundations for a rigorous, scientific study of the language and for the first time provides ample quotations from the classical authors to illustrate rules and usage. The Latin of the humanists, as best exemplified perhaps in Poliziano, is a new kind of language, faithful in spirit, lexicon, and general structure to the language of Rome, but less complicated in syntax. ${ }^{26}$ It has a looser flow; the tensions of Ciceronian prose, the gradatio or build-up of the period in an ascending and descending curve are no longer so much in evidence. Interspersed with the longer and rounded periods are shorter sentences and aphorisms, making for a more nervous or sinewy style. This is particularly true of the epistolary style, as may be seen in Cicero himself. The rich and varied Latin style of Erasmus' letters belongs firmly to this tradition. Through his incredibly thorough knowledge of the Latin classics and his reading of the best humanist writers he evolved several decades later a style that was the direct descendant of the Italian writers of the Quattrocento. Long before writing the Ciceronianus he learned the lesson that Poliziano imparted to Paolo Cortesi on the correct use of imitation, given in criticism of a group of letters Cortesi had sent him. ${ }^{27}$ Poliziano repeats Quintilian's ridicule of those who think they are kin to Cicero because they use one of his favorite clausulae, esse videatur. With his usual perspicuity Erasmus remarked in one of his letters ${ }^{28}$ that none of the devotees of Cicero could successfully reproduce even one of his periods. It is in this rather intangible quality of prose rhythm that Erasmus shows his true mastery of Latin, something that can be attained only by one who has a good ear for the native cadences of the language.

The importance of letter-writing in the time of Erasmus cannot be emphasized enough. The letter served as an ambassador, the vehicle in which the writer could best demonstrate his own broad culture and purity of Latin style, while at the same time paying homage to the recipient in 
its courtliness and elegance of language. ${ }^{29}$ Letters were copied out, passed around to friends, and read aloud again and again in the presence of others. There is the famous example of Poggio's letter of congratulations to Alfonso of Aragon, whose reception is described in a letter of Bartolomeo Fazio in Poggio. ${ }^{30}$ The lengthy epistle was not sent directly but confided to humanist friends in Naples, who had it copied on parchment in an elegant hand and delivered personally by Antonio Beccadelli to the king while he was engaged in a tourney of fowling. It was then read aloud before his entourage, who gave voice to their admiration of its lofty rhetoric and graceful turns of phrase.

Against this background I should like to look first at some of the early letters of Erasmus, when he was practising his pen and whiling away an idle moment, as he says in the introduction to the Epistolae ad diversos. ${ }^{31}$ The letter of the fourteen-year old schoolboy to his guardian, Pieter Winckel, though a bit awkward in its redundant and peremptory tone, still exhibits a precocious fluency in Latin. This may very well be the letter referred to in the letter to Grunnius and in De conscribendis epistolis as eliciting the wry remark from its recipient that in future the young man should include a commentary with his letters. ${ }^{32}$ As a matter of fact, it merely contains a banal phrase from Ovid's Ars amatoria and a brief adage, pale harbingers of what was to come. His early reading of Plautus is also evidenced in the use of a rare Plautine verb, licitor, 'to bid.' A youthful example of Erasmian terseness of phrase, although somewhat unvarnished and halting in its rhythm, adds point to the end of the letter: 'Si rogatus differt, vel iussus mittat' / 'If he demurs at a mere request, perhaps he will deliver when ordered. 33

The second letter printed in Allen, a touching, affectionate note to a nun named Elizabeth, already shows more assurance of style. Erasmus is not averse to using a Christian formula of address, 'soror una omnium in Christo carissima,' rather than the standard phrases. One of the 141 variations of the phrase 'tuae litterae magnopere me delectarunt' from the bounty of the De copia $^{34}$ provides a graceful opening, followed by a simple but finely articulated Ciceronian sentence: 'Prae se ferunt enim singularis tuae erga me benevolentiae, quam semper mihi conciliare studui, certissimum argumentum' / 'For it gives most certain evidence of your singular goodwill towards me, which I have always been at some pains to earn.' The rest of the letter pursues the theme of the steadfast friendship of the nun contrasted with the infidelity of fair-weather friends. Two couplets from Ovid's Epistles from Pontus are enlisted to reinforce the point. 
The direct colloquial style of Plautus and Terence is more in evidence in an early letter to his brother. It begins with two rapid-fire questions that function as a mild remonstrance: 'Itane totum fratrem exuisti? Itane prorsus Erasmi tui tibi cura recessit?' / 'Have you completely laid aside the role of brother? Has concern for your Erasmus wholly fled your heart?' The language is deliberately affected, ending in a Virgilian dactylic rhythm to arrest the attention of the recipient. The entire first paragraph of the letter is sprinkled with phrases from the colloquial Latin of the comedies or from Cicero's epistolary style, expressions like 'plane excidi' / 'you have altogether forgotten me' and other adverbial reinforcements, like apprime, prorsus, profecto, propediem. It all sounds very much like the Latin rehearsed in the Colloquiorum formulae. In the second paragraph Erasmus gives vent to his sincere affection for his brother, using expressions that might well be found in Cicero's letters, but again with a tinge of Virgil, as in the idiom te ore ferens. ${ }^{35} \mathrm{He}$ writes: 'Te ore, te animo ferimus; te cogitamus, te somniamus, de te nobis frequens cum amicis sermo est' / 'Your name is on my lips and in my heart; I think of you and dream of you and speak of you often with my friends.' The prose rhythm here is still uncertain, more akin to Church Latin or St Augustine.

Chief among these friends, as Erasmus relates to his brother, is a fellow countryman, Servatius Rogerus, whom he describes as a youth of beautiful disposition and very agreeable personality. With the next letter is initiated the series of letters to Servatius that have caused some embarrassment to later readers, and certainly would have embarrassed Erasmus himself if he knew they had been made public, although he did allow these letters from his monastery days to be copied into a letter-book, as may be deduced from a letter to a friend of his youth, Franciscus Theodoricus (Ep 186). Allen is reluctant to consider them as a chronicle of a true emotional attachment of the young monk, inclining to interpret them as epistolary exercises like those suggested in De conscribendis epistolis. ${ }^{36}$ D.F.S. Thomson has reinforced this view, giving 'literary imitation as the motivating force, ${ }^{37}$ and citing very similar language found in the letter-book of a monk named Robert Joseph of Evesham written at about the same time. For my part, these ardent, affectionate words of the young Erasmus to his fellow monk evince much more than literary conventions. If they were mere exercises, I should think he would have used a fictitious name. The same statements are reproduced in poetic form, which allows for even more exuberance, in several youthful poems, which Reedijk assigns to this same period. ${ }^{38}$ It seems clear to me that Erasmus was under the influence of a passing emotion, a sincere and deeply felt admiration for his confrère. 
Underneath the rhetorical flourishes one can perceive a transparent honesty, a fear of rebuff. As might be expected, there is much of Ovid here as well as of Virgil, Horace, Terence, and even a tag from Juvenal, a copy of whose work had just been delivered to Servatius out of the store of books left to Erasmus by his father.

If we were to attempt to categorize the second of these letters according to the ancient types, it would have to be described as a curiously involuted letter of consolation. In discussing this genre in De conscribendis epistolis Erasmus counsels indirection, the transference to ourselves of another's feelings of grief. Thus in writing to Servatius Erasmus pleads that although he seeks to give consolation, he is more in need of it himself. Yet he intimates that the cause of Servatius' troubles is the latter's attempting to conceal the corresponding affection that he feels for Erasmus, which is the cause of his anguish. The fourth letter of the series (as printed in Allen, although we cannot be at all sure of the chronology) is the most effusive, full of protestations, antitheses, rhetorical questions, the laying bare of wounded feelings. After indulging in these outpourings Erasmus puts himself into his respondent's place, as he often does, and gives expression to Servatius' indifference in language that is quite unemotional, 'Quid rerum tibi vis fieri? quid a me exigis?' / 'What on earth do you wish me to do? What do you want of me?' The answers of Erasmus by contrast are charged with emotion, evoking the diction of the elegiac poets and the Fourth Book of the Aeneid: 'excrucior,' 'torqueri,' 'adamantes redamant,' 'tui amore pereo.' In another letter (Ep 9), Erasmus is carried away with joy at the reception of a favourable letter from Servatius, which is not extant. This gives him an opportunity to elaborate on the commonplace of a letter taking the place of the sender, and bringing the two into each other's presence, for which thought a line from Virgil is aptly brought to bear, 'Absens absentem auditque videtque 39 / 'By absent heart the absent heard and seen.'

With the passage of time the ardour of the letters cooled and was replaced by a more lofty and abiding passion, the study of good letters. Now Erasmus firmly takes the upper hand and scolds Servatius for gathering together at random phrases from Bernard or Claudian to patch on to his own work, which in the end, he says, is not to compose a letter, but collect one ('literas non condere sed colligere'). ${ }^{40}$ Repeating Cicero's advice to Atticus, quoted also in De conscribendis epistolis, he recommends spontaneity, 'quidquid in buccam venerit ${ }^{41}$ 'whatever comes into your head.' The mood then becomes exhortatory, a series of crisp imperatives that recall the examples given in the long section on letters of encourage- 


\section{2 / Renaissance and Reformation}

ment in the essay: "excute torporem, pusillanimitatem exue, virum indue, tandemque vel sero operi manum impone'42 'Shake off sluggishness, strip away all faint-heartedness, play the man and, at long last, even at the eleventh hour, set your hand to the task.' It is interesting and touching to read a letter of many years later when Servatius had become Erasmus' superior in which the now famous scholar humbly writes to his former friend and notes that in the letter of his superior he sensed a spirit redolent of feelings entertained toward him in the past. But now a new tone and protocol is required: quondam sodalis suavissime, nunc pater observande / 'Once my sweetest companion, now my revered father. ${ }^{43}$ This letter, too, was never published but it seems that it was allowed to circulate, for under the guise of a humble letter to his superior it was really written for a wider audience.

The first few letters to Cornelis Gerard of Gouda, ${ }^{44}$ Erasmus' senior by six years and an established poet, are written with obvious care and as a consequence are somewhat lacking in spontaneity. The syntax is more complicated and the politeness seems strained. But as the correspondence continues, Erasmus becomes more free, as if he felt more assured of his stylistic superiority. When Cornelis presumes to question Erasmus' literary taste, however, specifically his admiration for Lorenzo Valla, ${ }^{45}$ the battle is joined openly. While softening his statement with the qualification that he was speaking only in jest, Cornelis manages to call Valla's reputation seriously into question, chiding Erasmus that he had given him as a model one who was notorious for being biting or caustic (mordax). The last lines of his letter contain a piquant barb that could not go ignored. He thanks Erasmus for confiding to him unjealously the names of his own teachers and the secret tricks of his trade (the word supellectiles in this context has a disparaging sense).

Erasmus in reply (Ep 26) first makes a rather elaborate apology in an effort to obviate any ill-feeling, explaining that if at times his words may seem somewhat flattering they must be interpreted as demonstrative of true affection, while if they should seem excessively frank Cornelis must not suppose that his love for him has diminished in any way. Pursuing this path of indirection Erasmus pretends to interpret Cornelis' comments not as a sincere expression of opinion, but as a literary exercise in the exposition of a paradox or as a pretence for something to write about. Without hesitation Erasmus accepts the challenge and takes up the cudgels against the slanders of stupid mummers of barbarism (he uses the Greek word mystae, initiates in a religious rite) and in particular against Valla's chief enemy, Poggio, whom he describes as possessing more loquacity than 
eloquence (the pun is more telling in Latin, "plus loquentiae quam eloquentiae'). ${ }^{46} \mathrm{He}$ defends his kindred spirit particularly from the charge of mordacity, which, he contends, frees him from the much more detestable vice of falsehood. Towards the end of the letter in a passionate peroration Erasmus summons the best of his Ciceronian style and solemn rhythms to exhort all men of letters to accord generous praise and the warmest affection to Valla, "qui tanta industria, tanto studio, tantis sudoribus barbarorum ineptias refellit, literas pene sepultas ab interitu vindicavit, prisco eloquentiae splendori reddidit Italiam, 47 'who with such intense industry, zeal and exertion refuted the follies of the barbarians, rescued literature from extinction when it was all but buried, restored Italy to her ancient literary glory.' Erasmus ends the letter on a jocose note, assuring Cornelis that he can entrust himself to this man without fear of being torn to shreds, and if he were to imbibe the lesson well, he might thereby add lustre to his writings - unless, of course, he was writing only for Dutchmen!

Not satisfied with this epistola exhortativa Erasmus later sent a humorous letter (Ep 29) in the form of a mock declaration of war, the letter acting as an emissary to demand satisfaction for the denigration of Valla's writing. The ultimatum is delivered at the outset: 'Either you resume good relations with my friend, Lorenzo Valla, or I declare open war upon you.' As he does frequently, Erasmus imagines the response of the recipient in a kind of dramatic repraesentatio, 'Unde subita turba?' / 'Why the sudden rumpus?' The parody is peppered with phrases taken from the poets, like the Virgilian horresco referens ('I shudder at the very words'), and an expression of indignation used in the comedies of Terence, os impudens! / 'What gall!' that Cornelis could give the name of 'croaking crow' to the most eloquent of men, who would more fittingly be called the 'marrow of persuasion.' Only in the last few lines does Erasmus drop the comic tone, saying: 'Are you laughing, and do you think I am joking? Laugh as much as you like, but do not imagine that all was said in jest.' He then reminds Cornelis that it does him no credit to attack Valla, whom only a barbarian could dislike but not a faithful devotee (the word mystes is used again) of literary culture. While it is true that Cicero often indulges his sense of humour, it is usually a question of puns or light banter, but nothing as sustained as this kind of letter of Erasmus, of which there are numerous examples. In De conscribendis epistolis, under the heading of the humorous letter, ${ }^{48}$ reference is made to Cicero's correspondence with Trebatius and his exchange of witticisms, usually of a gastronomic nature, with his Epicurean friend Papirius Paetus, but Erasmus' model seems to be more that of the Italian humanists, especially Poliziano, whose badinage could often 
become quite strident. It is clear, however, that Erasmus' intention here was to give voice to a serious matter under the guise of laughter (ridentem dicere verum, as Horace says). ${ }^{49}$ It is noteworthy that these are the only letters from his monastic days that find admittance into the Farrago, and in the later printing of them in the Epistulae ad diversos he adds the superscription, scripsit puer.

Dropping the jocular tone, Erasmus professes his continued devotion to his friend in a subsequent letter, in which he mentions completing 'that oration of yours,' evidently the Antibarbari, which he was working on at that time. In this way he makes up for any insinuations that he may have made, even in a joking manner, to Cornelis' deserting to the side of the barbarians.

The opening period of a letter of gratitude to an unknown friend, accompanying the gift of a manuscript of Terence, is a fine example of a graceful expression of thanks, combined with a humble apology for not being able to render due thanks. The language has an elegant balance and cadence: 'Quoties animo meo recursant cum multa tum maxima tua in me merita, imo tuus liberalissimus animus, toties ego meam fortunam incuso, malignam invidam iniquam voco, per quam mihi non sit facultas, ubi tuum abunde expertus sum, mei vicissim in te declarandi amoris' ${ }^{50}$ / 'Whenever your many great kindnesses or rather your most generous disposition recur to mind, I reproach my ill fortune, mean, grudging, unfair I call it, through whose fault I am denied the ability of signifying my affection for you in return for the lavish attentions you have bestowed upon me.' The asyndeton of the three adjectives, the homoteleuton, and the austere rhythm of the parenthetical clause are effective. Latin likes the juxtaposition of personal pronouns, as exemplified here: 'tua in me merita'; 'ubi tuum ... mei vicissim in te.'

Letter 87 to a certain Johannes Falco, of whom very little is known, is a curious example of a humorous letter, which might more properly be called an anti-letter. It is in the same mould as the supposed letter to a would-be courtier in the De conscribendis epistolis, ${ }^{51}$ but from beginning to end it is a complete parody of the very form of the letter. It seems to have been written when Erasmus was paying court to his prospective patroness, Anna van Borssele, from which unpleasant occupation he probably found some release in this jeu d'esprit. In place of the polite opening, the reader is greeted with 'Tu cave salutem a nobis expectaveris' / 'Don't expect any greeting from me!' and the usual protestations of friendship and affection' are replaced by 'Devoveo te, quoties tua mihi convicia in mentem veniunt' / 'I curse you everytime your insulting remarks come to mind.' The friendly 
advice proffered is of a piece with the rest: 'Frustra sapit qui sibi non sapit' / 'Wisdom is of no use if it does you no good.' 'Mirare literas et lauda, sed lucrum sequere' / 'Admire literature and accord it praise, but pursue lucre.' 'Cutem cura ante omnia'52 'Look after your own skin above all.' And so to the end where the polite closing formula is inverted to 'Tu tibi vive et vale tibi et te solum, ut facis, ama' / 'Live for yourself and look after yourself, and love, as you do, yourself alone.' Echt Erasmus, one more facet of his chameleonic epistolary style, which blinds the recipient by its elusive tone.

The mood of jest, which often betokens confidence, pervades Erasmus' letters of this period as he travelled about France and then took ship to England. They are familiar exchanges with his friends Jacob Batt and Fausto Andrelini. A letter (Ep 103) from England to Fausto, who, as the editors of the CWE remark, ${ }^{53}$ seems to have brought out the frivolous streak in Erasmus' character, is a good example of the simple informative letter discussed in the De conscribendis epistolis, ${ }^{54}$ and resembles very much in style the one given there. Brevity and ellipsis are of the essence in this form of letter. From the opening phrase the colloquial tone is contagious. Such letters dispense with any formal greeting. 'Deum immortalem, quid ego audio?' / 'Good God! What is this I hear?' He reports on his reception and sojourn in England and his adaptation to courtly manners, referring to himself humorously in the third person: 'Ille Erasmus, quem nosti salutat paulo blandius, arridet comius, et invita Minerva haec omnia' / 'The Erasmus you knew is a bit more charming in his salutations, smiles more politely and all of this he does against the grain.' 'Quid mea? satis procedit.' / 'What do I care? It's going very well.' 'Tu quoque, si sapis, huc advolabis' / 'You too, if you have any sense, should wing your way over here.' 'Quid ita te iuvat hominem tam nasutum inter merdas Gallicas senescere' / 'What good is it for a man of your taste to grow old in the midst of French excrement.' Nasutum is a good colloquial word, found mostly in Martial, meaning a man with fine taste (in Italian, nasuto, and in French avoir bon nez). The last part of the letter is a delightfully exaggerated description of the fair nymphs of the English countryside, whom Erasmus describes as being prodigal in their lavishing of kisses, on arrival, on taking leave, on one's return, in a word, wherever you turn, 'suaviorum plena sunt omnia' / 'all is filled with kisses.' Allen remarks rather solemnly that 'the condition of society described may be taken to be that of an English country house at this period. ${ }^{55} \mathrm{He}$ also notes that the letter was probably written from Bedwell in Hertfordshire, where Mountjoy's father-in-law, Sir William Say, had an estate, but since such a 
barbaric place name could not be used in a letter to a literary friend, Erasmus writes vaguely: ex Anglia. Spontaneous as they appear, such letters, of which the correspondence is full, are written with great garb, and Erasmus is quite unrivalled in this form. As he mentions in this letter, he could be quite a skilful courtier, even if it was contrary to his temperament. He did not hesitate to have these letters published in the Farrago as examples of this urbane style.

The correspondence with Colet is of quite another cast. Colet was the first to write (Ep 106), on the recommendation of Richard Charnock, prior of St Mary's College, where Erasmus was staying. It is a formal letter of welcome from the English world of scholarship, in which Colet praises the visitor's virtue as well as his learning. The Dean of St Paul's makes specific reference to a complimentary letter that Erasmus had inserted in Gaugin's history of France, which he had obviously seen recently in Paris. Colet is ecstatic in his praise: 'Erat mihi quasi specimen quoddam et degustatio perfecti hominis et magnae literaturae et multarum rerum scientiae ${ }^{56} /$ 'It was to me a very pattern and example of human perfection, of great literary learning and knowledge of various subjects.' In contrast to Colet's plain style Erasmus delivers himself of an elegant reply (Ep 107), introduced by a suitably modest but well-turned sentence: 'Si quid omnino in meipso agnoscerem, Colete humanissime, vel mediocri laude dignum, iactarer profecto cum Hectore illo Neviano laudari abs te, viro omnium facile laudatissimo' / 'If I saw anything in myself, most kind Colet, that deserved even a modicum of praise, I should now surely be boasting, like Hector in Naevius' play, that I receive praise from the praised, for you are easily the most praised of all men.' Aside from the learned quotation taken from Cicero's letters, ${ }^{57}$ what is worthy of note here is the elcgant figura etymologica linking the successive commata or divisions of the sentence: 'laude dignum ... laudari abs te, viro laudatissimo.'58 The picture he paints of himself with all modesty is justly famous, composed of a series of rhetorical antitheses. Having presented himself, he then draws a picture of his correspondent as manifested in his style, through which, Erasmus says, he could clearly perceive a kind of image of his personality (tui animi simulacrum), a common figure of epistolary convention. He qualifies his style as calm, tranquil, unaffected, flowing like a pellucid stream from the great riches of his mind; even and consistent, clear and simple and full of modesty, without a trace of anything tasteless, involved or confused (the last tricolon is articulated in an emphatic rhythm, each adjective one syllable longer than the preceding: scabri, contorti, conturbati). The truth is, as Erasmus confessed much later, Colet was impatient with the rules of 
grammar and though eloquent by nature he never developed a style sufficiently learned in his own estimation for the writing of books.

The next two letters constitute the theological dispute with Colet on the nature of Christ's agony in the garden of Gethsemane. They are interesting as a transference to a letter of an oral discussion of a religious subject, forming the intermediate stage of the treatise that was then revised, rearranged and enlarged for publication in the Lucubratiunculae in 1503. These original versions, as printed by Allen from the Gouda manuscript, show the greater freedom allowed in the epistolary form compared to the final published work. Erasmus is determined to show that such subjects can be treated in an eloquent manner rather than in the stammering, foul and squalid style of the scholastics, as he describes it. ${ }^{59}$ In refuting his opponent, Erasmus has recourse to logical principles employed in oratory that he had learned from the De inventione of Cicero and had recorded in De conscribendis epistolis. He terms this procedure the method of inference ${ }^{60}$ whereas he accuses Colet of using a specious type of rhetorical argument in which the proofs are omitted. ${ }^{61}$ The argument ex antecedentibus, or simple conclusion, is employed, which he illustrates with some of the very same examples used in his treatise on letter-writing. ${ }^{62}$

During his often frustrating attempts to gain patronage in the Tournehem-Saint-Omer circle Erasmus was sometimes constrained to write rather fawning letters against his inclination and better judgment. The first such letter was one addressed to Antoon van Bergen, Abbot of St Bertin at Saint-Omer. It begins with a well-rounded, chancellery-style period: 'Cum incredibilis humanitas tua, pater amplissime, cumulatioribus beneficiis me sibi teneat obaeratum quam ut (etiamsi capitis huius auctionem fecero) vel sorti soluendae par esse possim, ego tamen grati animi conatum cuperem officio literarum utcunque significare, ne pessimum nomen iure videri possem, si aes alienum vel qualicunque opera redimere dissimulassem'63 / 'Although your extraordinary kindness, most venerable Father, holds me bound in your debt by such an accumulation of favours that I am in no position to repay the principal, even if I should auction off my very life to do so, yet I should like at least to signify in some way in a letter my instinctive feeling of gratitude, lest I justly earn the reputation of being a bad risk in the repaying of debts, as indeed I would if I were to neglect repaying my debt by some gesture.' As the letter proceeds, the praise of the abbot becomes ever more lavish, with reference to his majesty of bearing (corporis heroica species), splendid health (valetudo felicissima), and Herculean strength of spirit (Herculeum animi robur). Buoyed up on his own flow of language, Erasmus suddenly catches himself 
up short, as it were, in the middle of a developing period, which had grown so fulsome that he could not give it final shape: 'et in amplitudine humanissimus et in humanitate amplissimus.' Perish the thought! Erasmus is beginning to sound like Gnatho, the parasite of Terentian comedy, whose emulators he so despised. But he puts an end to this display of verbosity, which he calls makrologismos, and comes finally to his request, not without one final recapitulation of the bishop's physical and mental endowments.

A similar tone is to be found in the first letter of Erasmus to be published, which constituted, fittingly enough, his first appearance in print (Ep 45). Hastily composed to fill the last two printed pages of Gaguin's history of the French, which appeared in $1495,{ }^{64}$ currente calamo, it was drawn out to greater length than was required. ${ }^{65}$ Yet with this single effort Erasmus was able to gain entry into the circle of Parisian humanists and indeed beyond, since it was also read by Colet, who was inspired by it to write the letter of encomium previously mentioned. The first part of the letter is a rather tedious elaboration of the Horatian sentiment that the great deeds of kings and leaders will soon die away or be eclipsed by time unless they be enshrined in writing. This is the glorious task that Gaguin has accomplished, which will occasion immense pleasure to all lovers of Latin literature. The series of superlatives and tricola employed are decidedly overdone: 'Galliae tuae splendidum imprimis, magnificum ac (ut ita dixerim) triumphale, denique tua doctrina, tua eloquentia, tua pietate dignissimum' (lines 8-10) / 'a work destined first of all to bring to your country of France dignity, prestige and, what I may call triumphal splendour, and finally one most worthy of your scholarship, literary skill and patriotism.' Erasmus feels he must apologize for the unclassical use of the adjective triumphale, and there are other instances in the letter of post-classical usage, e.g., the words, laudatiuncula (60), luculentia (93), vivacitas (96), and phalerare (124). Further awkwardness is manifest in his complimenting Gaguin on his ability at compression of subject matter, 'et prolixe brevis et breviter prolixus' (lines 99-100), but all in all, it is impressive for a publishing debut even if it does smell undeniably of the lamp. In any case, Erasmus did not see fit to include it in his collections, nor did Gaguin. The rather severe doyen of Parisian humanists had reproved the aspiring scholar for using excessive flattery in an earlier letter addressed to him, which is no longer extant. It seems that Erasmus took the reproof to heart and wrote a second letter, likewise not extant, which Gaguin praises for its admirable arrangement of words and nobility of sentiment (verborum structura et sententiarum maiestate), ${ }^{66}$ but in the pub- 
lished preface to the history Erasmus seems to have relapsed once again into hyperbole.

Another early letter found its way independently into print but was never included in any collection (Ep 93). It is an exhortatory preface to a group of prayers composed for the ten-year-old Adolph of Burgundy, heer van Veere, which appeared as the first piece of the Lucubratiunculae (Martens, 1503). ${ }^{67}$ At the beginning it exhibits more the characteristics of the panegyric, but then it takes on the tone of an exhortatory letter in blandishing and whimsical language suitable to the young recipient. In Latin the diminutives have a pleasant charm that is not easily transferrable to English: 'blesa ac vixdum firma lingula Graecae pariter ac Latinae verba meditaris'68 / 'your lisping and faltering tongue reciting Latin and Greek,' or 'formosula isto et generoso ore ac vocula amabili' / 'your dainty, well-bred lips and charming little voice.'

The first formal appearance in print of a group of Erasmus' letters is somewhat disguised. They form the latter portion of a brief anthology of poems and panegyrical letters dedicated to Pope Leo X concerning expeditions against the Turks, printed by Froben in August 1515. The titlc poem De expeditione in Turcas elegeia by a little known Italian humanist, Janus Damianus, is followed by a letter of Jacobus Piso, a friend of Erasmus and envoy of Leo X, on the war between the Poles and the Lithuanians, another of a certain Henricus Penia and one of King Sigmund of Poland. It seemed opportune to the printer to insert at this point an extended homage to Leo X, defender of Christianity, apostle of peace, and protector of the humanities. Erasmus first wrote this letter (Ep 335) to gain permission from the Pope to dedicate his editorial work on St Jerome to him. Given this opportunity to assure the letter's wider currency, he re-worked and amplified it extensively. In this case the process of revision can be accurately studied, for the original version exists in manuscript. ${ }^{69}$ In addition to rounding out individual phrases and adding sentences more applicable to the context of the war against the Turks, Erasmus composes afresh long developments, e.g., a section of twenty lines in the Allen text (lines 143-63) on the history of all the pontiffs who bore the name of Leo and another of fourteen lines (171-84) on the two wars that must be waged by Christians, one against wickedness and the other on a narrower front against the impious opponents of Christianity. The amplification of the existing text is done with great rhetorical skill. It is a natural and unforced expansion of the original material, of which I shall give but a single example. In awarding praise to the Medici family that had produced so many followers of Cicero and Virgil, of Plato and Jerome. 
Erasmus said in the first version that this one thing alone should rouse high hopes in all men of learning 'ut vel haec una res studiosos omnes summam in spem debeat erigere. ${ }^{770}$ Changing 'haec una res' into 'hoc unum omen,' he easily adds an appositive clause with the effect that the phrase debeat erigere, not a very strong rhythm for the end of a full period, now becomes the preparatory rhythm at the end of an incisum, or shorter member, leading into a grander resolution of the period: "minimum providentia Leonem orbi datum, sub quo praeclarae virtutes, sub quo bonae artes omnes reflorescent' / 'by the providence of God a Leo has been given to the world under whose guidance all noble virtues and all liberal arts may once again flourish.' Halkin comments that 'la lettre est gâtée par une obséquiosité peu érasmienne, ${ }^{, 71}$ but I think he fails to consider that it becomes an outright panegyric in its new expanded version, and is well adapted to that form.

This letter is printed in first position, as it should be, in view of its importance and elaboration, although it is posterior in time to the letters written from London to his two most influential patrons in Rome, Cardinals Raffaele Riario and Domenico Grimani. Both of these are models of an accomplished, curial style, but do not lack the distinguishing marks of vividness, urbanity and learned allusion. The second version of the letter to Riario is again greatly amplified for publication. To both prelates he expresses his love and nostalgia for the city of Rome with similar words and sentiments, but not wishing to reduplicate phrases, he demonstrates his abundance of style and ability at subtle variation. To Riario he writes 'non possum non discruciari Romanae urbis desiderio quoties animo recursat ${ }^{72}$ 'I cannot but be tormented by a longing for the city of Rome whenever I recall ...' and here he records the city's various delights. To Grimani he re-phrases his words: 'neque enim non possum tangi Romae desiderio quoties tantus tantarum simul commoditatum acervus in mentem venit'73 / 'I cannot help being effected by a longing for Rome when I bethink myself of its great store of immense advantages to be enjoyed all at one time.'

Elegant words of encomium are also reserved for the pope and for the Archbishop of Canterbury, making these two letters the worthy companions of the longer panegyric. The fourth and last component of the volume is the famous letter to Dorp in defense of the Folly. The original letter, which has not survived, was shorter than the one printed in this collection, as we know from passages in other letters. For all its great length the letter is a pleasure to read, a model of eloquence and equanimity, a good example of Erasmus' milder polemical style. The four letters were re-published in 
the same year of 1515 by Martens in Louvain, and in the following year in Leipzig and Cologne with the new title Erasmi Roterodami epistolae. Thus, as Halkin remarks, 's' achève cette opération publicitaire de grand style, ${ }^{74}$ an Erasmus-Froben production.

The second collection, as the title Epistolae aliquot virorum illustrium ad Erasmum indicates, is more an advertisement of Erasmus' illustrious correspondents than of himself. A list of them is given in the preface to the volume written by Pieter Gillis. Appearing in the same year as the Novum Instrumentum, it places great emphasis on letters that are connected with the reception given to this work. The first three pieces are taken from the 1515 volume, followed by a response of Leo X to Erasmus (Ep 338) and a new letter of Erasmus to Leo X (Ep 446), which resumes the earlier correspondence concerning the papal favour he was seeking. The delicate matter of the further dispensation is not broached in the letter, but left to be communicated by word of mouth by the bishop of Worcester, Silvestro Gigli. The letter is framed in most exquisite and formal Latin, as befits such a recipient. Gillis, no doubt with Erasmus' complicity, cleverly joins to this set of letters an eloquent letter of recommendation from Leo $\mathrm{X}$ to Henry VIII (Ep 339), professing his high regard for Erasmus. England is well represented in this collection with letters from More, Archbishop Warham, Colet, Ammonio and Bullock.

Letters from the greatest humanists of France also find their place in these pages. There is a brief but very eulogistic letter from Jacques Lefèvre d'Etaples (Ep 315) to Erasmo Roterodamo, literarum splendori. It might be said in passing that Lefèvre's praise is not enhanced by his style. The first letters of the long and intricate exchange with Budé are also included. In his introductory letter (Ep 403) Budé accords glowing tribute to the Novum Instrumentum, pleased in turn that Erasmus had given him very honourable mention in one of his notes (omitted in all editions of the New Testament after 1527). Towards the end of the letter, however, he indulges in a bit of criticism of Erasmus for wasting his talents on what he calls with a fancy Greek word, leptologemata, 'bagatelles.' This accusation nettled Erasmus, as we see in his response (Ep 421), which is a masterpicce of clever refutation while still sustaining a most deferential tone. He turns Budés criticism to his own advantage, conceding that he finds everything he writes trifling and wonders why others, even men in high places, make so much of his work. With ironic self-deprecation he claims for himsclf that he has outdone his predecessors in diligence, at any rate, if not in erudition. As for trivialities, he exclaims: 'Think how many frivolous notes there are in Jerome's emendation of the Psalter!' (lines 119-20). To this letter Erasmus 
later added a kind of postscript (Ep 441), replying in detail to some of Budé's philological questions. This exchange saw print early, for Erasmus stood to gain in the matching of wits with the French savant. Indeed it was a rather unequal contest.

From the German world the collection is adorned with two letters from Zasius (Epp 310 and 406) and one from Pirckheimer (Ep 409). The former, a learned jurist at the University of Freiburg, assures Erasmus that his letter was passed from hand to hand and the faculty clamoured for it, full of admiration for such a fountain of the purest style. He counts himself blessed for the privilege of having received a letter from the divine Roterodamus, and confesses that he has fallen under the spell of Erasmus' splendid rhetoric. The feeling was mutual in this case, for Erasmus considered Zasius to be the only German who could write Latin and compared him to Poliziano in his felicity of style. All the more reason why he should be included in this early collection. The other letter from Germany is from the hand of Willibald Pirckheimer, town councillor of Nürnberg. It is a carefully written note in praise of the New Testament and bears testimony to the great popularity of Erasmus noster in that part of the world. The flattering closing salutation, 'bene valeas, gloria et splendor humani generis,' could not but add lustre to the volume. As further proof of his renown in the German world Erasmus prints a letter from Urbanus Regius (Ep 386), writing for Duke Ernest of Bavaria, to Joannes Faber, chancellor to the bishop of Basel, asking him to deliver an invitation to Erasmus to assume a chair at the University of Ingolstadt. Once again the praise is lavish and abundant. The Duke's representative inquires whether there could be any terms on which 'this great champion of humane studies could be induced to give regular courses and water their desert with the manifold rivers of his eloquence and erudition.' It is significant that Erasmus does not include his two answers to this request, the first being a rather hurried note of refusal, which he considered bricf and unpolished and therefore not worthy of inclusion at the moment, and the other a letter to Regius recommending Glareanus for the position, likewise not included as contributing little to the fame of the writer.

It will be seen that these first two public collections, after the very experimental apprenticeship, are very cautious and conservative. The first sizcable collection, the Epistulae sanequam elegantes of $1517,{ }^{75}$ containing thirty-five letters, of which thirty-one are published for the first time, ${ }^{76}$ gives greater scope for variatio. The title itself, 'exceptionally clegant epistles, ostensibly devised by Gillis, who wrote the preface, is a sure indication of Erasmus' ambitions for the volume. It is clear that Erasmus 
was directly connected with its publication, as he indicates in a letter to More (Ep 543:30-2), telling of his intentions to arrange for the printing of another volume of letters to bring them before a larger public. Moreover a letter from Rutgerus Rescius (Ep 546), corrector for the press of Martens, confirms Erasmus' direct involvement. In the opening letter to Capito he inquires about a passage that he cannot understand and also asks if Erasmus has anything that could be added to fill the space left by the printer for some preliminary material. Erasmus responded by supplying a letter to Étienne Poncher, bishop of Paris, which turned out to be too long and had to be compressed into the space by the use of every possible abbreviation. The argument of the letter fits in very well with that of several others in the collection, Erasmus' hesitance to accept the post at the new Collège Royal offered to him by the King of France.

The choice of letters and especially the order in which they are set out are again très soigné. The letter to Wolfgang Capito, which heads the collection, is indeed a "classic statement of the aspirations and programme of humanistic reform,' as the editors of CWE remark. ${ }^{77}$ Erasmus is careful to single out all the monarchs and prelates who showed themselves sympathetic to his concerns: Leo X, Francis I, Charles V, Henry VIII, Cardinal Ximenes and the Emperor Maximilian, paying due homage to each. He speaks in this opening letter of the advent of a new golden age (Ep 541:13), a theme to which he returns frequently at this time.

After the letter to Poncher, inserted at the last moment, it is the turn of Guillaume Budé, represented by six new exchanges between the two paladins of learning, set in friendly confrontation, as Gillis had promised in the preface. Then follows, very tactfully, a letter from François Deloynes, close friend of Budé since their youth, which contains great praise for works recently issued from Erasmus' workshop, and wishes God's blessings on both scholars. At this point come two more letters between the two men, taken from the 1516 collection. A letter from Guillaume Cop, reinforcing the offer from Budé, Erasmus' polite response, and the eloquent eulogy to Francis I, all concern themselves with the invitation to France. A similar offer from Luigi di Canossa, bishop of Bayeux, is the subject of the next exchange of letters.

In contrast to these official letters is a very affectionate and respectful letter from the Swiss poet, Henricus Glareanus, (Ep 463) who expresses his indebtedness to Erasmus for having taught him the philosophy of Christ (Christum sapere), a compliment that the theologian would most certainly be pleased to have spread abroad. ${ }^{78}$ The same sentiment is repeated in Glareanus' poem to Oswald Geisshüssler, which follows, 
together with a hecatostichon of Glareanus to Erasmus and a poem of his teacher, Hermann von dem Busche, in honour of Erasmus. It has been objected that the insertion of these hors-d'oeuvre spoils the continuity of the collection, ${ }^{79}$ but I think not. They serve the same purpose of confirming the notoriety of the great man, and they are closely connected in theme with the letters they accompany.

It will not be possible to comment on the place of each letter in the collection, but it should be obvious by now that they were all carefully selected and strategically placed. There is only one letter that is not to or from Erasmus, viz., Ep 492, situated at about the halfway mark, written by Adriaan Cornelissen van Baerland to his brother Cornelis, which Erasmus obviously included as a convenient way to give a catalogue of his works, and of more importance, the estimate of them by learned men. This van Baerland does with great unction in reply to a request by his brother. In a burst of hyperbole he exclaims that the master 'has so enriched the Latin tongue that there is no need to complain so bitterly over the classical authors lost in the invasion of Italy by the Goths' (Ep 492:22-4). Later in the letter he speaks of Erasmus as 'a man clearly born for the restoration of humane studies' / 'homo nimirum ad restituendas literas natus' (Allen Ep 492:126-7). Such unsolicited good publicity could not be denied the privilege of publication.

One of the best accounts of Erasmus' epistolary style remains the letter of Christophe de Longeuil, himself no mean stylist, although he fell victim to the excesses of Ciceronianism, addressed to Jacques Lucas, Dean of Orlćans, which later reached Erasmus (Ep 914). Of Erasmus' style he praises its ars, subtilitas, lenitas, iucunditas / 'skill, subtlety, smoothness and pleasantness.' To these he might have added humanitas, above all, and true amicitia, ${ }^{80}$ not the calculated political virtue cultivated in the Roman republic. Later, in his preface to the Epistolae ad diversos ${ }^{81}$ Erasmus said modestly of himself that he might not seem wholly ill-equipped for the writing of letters. In that same place he insisted that letters that are deficient in true feeling and do not reflect a man's actual life do not deserve to be called letters at all. Those charges cannot certainly be levelled at Erasmus. Of all letter-writers he perhaps best illustrates the prescription in the treatise On Style attributed to Demetrius of Phaleron that a letter should be the image of the soul, $\varepsilon$ t $\omega \nu \psi \psi \mu \chi \eta s^{82}$ This was surely the impression left in his original recipients as it is still today, even when his image is refracted into another language, as in the splendid English renderings of $\mathrm{CWE}$. 


\section{Notes}

1 Cicero expressed this intention in a letter to Atticus $(16,5,5)$ : 'mearum epistolarum nulla

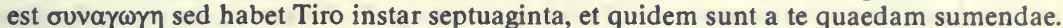
Eas ego oportet perspiciam, corrigam; tum denique edentur' / 'There is no collection of my letters, but Tiro has about seventy and I shall have to get some from you. I must examine and correct them. Then and then only will they be published.'

2 Cf Otto Seeck $Q$. Aurelii Symmachi quae supersunt, Monumenta Germaniae Historica VI, I (Berlin 1883) xxiii

3 Giorgio Pasquali Storia della tradizione e critica del testo (Florence 1962) 457

4 Cf Gianvito Resta L'epistolario di Antonio Panormita: studi per un'edizione critica (Messina 1954) 3.

5 F. Petrarca Le familiari ed Vittorio Rossi, Edizione nazionale delle opere di F. Petrarca $\mathrm{x}$-xiii (Florence 1933-42)

6 See Lucia Gualdo Rosa 'La pubblicazione degli epistolari umanistici: bilancio e prospettive.' Bullettino dell' Istituto Storico per il Medio Evo e Archivio Muratoriano 89 (1980-81) 369-92.

7 For an illuminating discussion of the importance of the order in which letters appear in a collection of Jozef IJsewijn 'Marcus Antonius Muretus epistolographus' in $\mathrm{La}$ correspondance d'Erasme et l'épistolographie humaniste (Brussels 1985) 183-91.

$8 \mathrm{Cf}$ H. Hunger 'Epistolographie' in Handbuch der Altertumswissenschaft XII Abt., V, I (Munich 1978) 197-239.

9 Cf Karl Zeumer Formulae merowingici et karolini aevi MGH Legum V (Hannover 1886).

10 A good synopsis of the teachings of the dictatores may be found in James J. Murphy Rhetoric in the Middle Ages (Berkeley 1974) chapter V 'Ars dictaminis' 194-268.

11 See John O. Ward 'From Antiquity to the Renaissance: Glosses and Commentaries on Cicero's Rhetorica' in James J. Murphy Medieval Eloquence: Studies in the Theory and Practice of Medieval Rhetoric (Berkeley 1978) 25-67.

12 Ronald Witt 'Medieval "Ars Dictaminis" and the Beginnings of Humanism' Renaissance Quarterly 35, 1 (1981) 17

13 For Giovanni di Bonandrea see James Barker 'The Ars dictaminis and Rhetorical Textbooks at the Bolognese University in the Fourteenth Century' Medievalia et humanistica S (1974), and for the treatise of Bartolomeo de Benincasa see Sandra Karaus Wertis 'The Commentary of Bartolinus de Benincasa de Canulo on the Rhetorica ad Herennium' Viator 10 (1979) 289.

14 'E insieme disperdeva con un solo assalto gran parte della precettistica involuta che attraverso secoli si era condensata a regolare i dictamina.' Giuseppe Billanovich Petrarca letteraria (Rome 1947) 4

15 Francesco Petrarca-Le familiari ed Vittorio Rossi (Florence 1933) 1.1.14

16 Ibid 1.1.16

17 'Aliter virum fortem, aliter ignavum decet alloqui; aliter iuvenem inexpertum, aliter vite muneribus functum senem; aliter prosperitate tumidum, aliter adversitate contractum: aliter denique studiosum literisque et ingenio clarum, aliter vero non intellecturum siquid altius loquaris.' 1.1.28

18 Erasmus De conscribendis epistolis CWE 25, 19 and passim. Juan Luis Vives De conscribendis epistolis ed Charles Fantazzi (Leiden 1989) 28-37.

19 Quintilian 11.1

20 'Nam et litterae sine rerum scientia steriles sunt et inanes, et scientia rerum quamvis ingens si splendore careat litterarum, abdita quaedam obscuraque videtur.' De studiis el 


\section{6 / Renaissance and Reformation}

litteris, 19 in Leonardo Bruni Aretino Humanistisch - philosophische Schriften ed. Hans Baron (Leipzig 1928)

21 The Latin text is contained in ASD 1-3 31-103 ed L.-E. Halkin, F. Bierlaire, R. Hoven, and an English translation is provided by Craig R. Thompson The Colloquies of Erasmus (Chicago 1965) 557-614. For the complicated history of the text see ASD 1-3:5-8.

22 CWE 25:60, ASD 1-2:292

23 It might be remarked in passing that exaggerated as these titles may seem to an English reader, many of them have survived in Italian and Spanish such as the Italian forms of address chiarissimo, pregiatissimo, etc.

24 This letter was first published by Gervasius Amenus of Dreux in his Lucubratiunculae (Paris 1513-14).

25 CWE 29-33, ASD 1-2:238-45

26 Spongano 'La prosa letteraria del ' 400 ' in Leon Battista Alberti Della famiglia (Florence 1946) vii-xxxii

27 The letters of Poliziano and Cortesi's response with Italian translation are contained in Prosatori latini del Quattrocento ed. Eugenio Garin (Milan 1952) 902-11.

28 Allen Ep 1885:150-6

29 As Cecil Clough remarks, "by the turn of the fifteenth century the letter was replacing the oration as the prime means by which scholars, and particularly those devoted to the cult of Antiquity, disseminated their ideas and made their case in scholarly controversy.' 'The Cult of Antiquity: Letters and Letter Collections' in Cultural Aspects of the Italian Renaissance. Essays in Honour of Paul Oskar Kristeller ed Cecil H. Clough (Manchester 1976) 33.

30 Poggii epistolae ed Tommaso Tonelli (Florence 1832-61) vol III 158-65. the letter of Fazio is contained in W. Shepherd Vita di Poggio Bracciolini trans T. Tonelli (Florence 1825) vol II, LXIX-LXXI. Cf Hélène Harth 'L'épistolographie humaniste entre professionalisme et souci littéraire: l'exemple de Poggio Bracciolini' in La correspondence d'Erasme et l'épistolographie humaniste (Brussels 1985) 143-4.

31 Ep 1206:24

32 CWE 2516

33 Allen Ep 1:14-5

34 CWE 24 349-54

35 Virgil Aeneid 4.11

36 Allen I, Appendix 3, 584

37 D.F.S. Thomson 'Erasmus as Poet in the Context of Northern Humanism' De Gulden Passer 47 (1969) 192

38 Poems 5-7, C. Reedijk ed The Poems of Desiderius Erasmus (Leiden 1956) 143-8

39 Virgil Aeneid 4.83

40 Allen Ep 15:37-8

41 Cicero Ad Atticum 12.1.2; 14.7 .2

42 Allen Ep 15:49-50

43 Allen Ep 296:236-7

44 Cf C.P.H.M. Tilmans 'Cornelius Agricola (c. 1460-1531), praeceptor Erasmi?' Rodolphus Agricola Phrisius 1444-1485. Proceedings of the International Conference at the University of Groningen 28-30 October 1985, ed F.A. Akkerman and A.J. Vanderjagt (Leiden 1988) 200-210. 
45 Ep 24:30-46

46 Allen Ep 26:49-50

47 Allen Ep 26:105-7

48 CWE 25:245

49 Horace Satires 1.1.24

50 Allen Ep 31:1-5

51 CWE 25:195-7

52 Juvenal 2.105; Horace Epistles 1.2.29

53 Ep 103 introduction

54 CWE 25:225

55 Allen Ep 103, introduction

56 Allen Ep 106:6-7

57 Cicero Ad familiares 5.12.7

58 Ep 107:2-3

59 Ep 108:33

60 Ep 111:80

61 Ep 111:52-3

62 Ep 111:203; CWE 25:112

63 Allen Ep 143:1-6

64 Cf Allen Ep 43, introduction.

65 It is interesting to note that in a later edition of the Compendium Erasmus' friend Cornelius wrote a dedication which he felt to be inadequate 'since his friend Erasmus had already given it excellent praise in that eloquent voice of his.' (Parcus te laudo, candidissime pater, quam dignus sis, tum quod primarias tue laudis partes meus Herasmus illo suo facundissimo ore occupavit.) Compendium, f108.

66 Allen Ep 44:2-3.

67 The letter is entitled 'Epistola exhortatoria ad capessendam virtutem ad generosissimum puerum Adolphum, principem Veriensem.'

68 Allen Ep 93:78-9

69 Allen Ep 333, introduction

70 Allen Ep 335:24-5

71 Léon-E. Halkin Erasmus ex Erasmo (Aubel 1983) 29

72 Allen Ep 333:30-1

73 Allen Ep 334:32-4

74 Halkin, 36

75 I consulted the exemplar in the Gemeentebibliothek of Rotterdam.

76 The four previously published letters are from the 1516 edition: Epp 388, 403, 421, and 441. The first of these, to Thomas More, is reserved for the last place in the new collection; 401 is a long letter from Budé; 421 and 441 are shorter letters of Erasmus to Budé.

77 CWE Ep 541, introduction

78 Erasmus omits Ep 440, which elicited Glareanus' response and in which he also asks for the poem. According to the editors of the CWE the original letter seems to have been destroyed. 
288 / Renaissance and Reformation

79 'L'unité du recueil est compromise par l'introduction, ça et là, de quelques poèmes sans rapport avec les lettres.' Halkin, 52

$80 \mathrm{Cf}$ the study of Yvonne Charlier Erasme et l'amitié d'après sa correspondence (Paris 1977).

81 1206:94-5

82 Demetrius On Style ed W. Rhys Roberts (Cambridge 1902) 227 